\title{
Combining Ability Studies for Growth and Quality Characters in Tomato (Solanum lycopersicum L.)
}

\author{
Y. Madhavi ${ }^{1^{*}}$, R.V.S.K. Reddy ${ }^{2}$ and C. Sreenivasa Reddy ${ }^{1}$ \\ ${ }^{1}$ Department of Vegetable Science, College of Horticulture, Dr. Y.S.R.H.U, Rajendranagar, \\ Hyderabad - 500 030, India \\ ${ }^{2}$ Vegetable Reasearch Station, Dr. Y.S.R.H.U, Rajendranagar, Hyderabad - 500 030, India \\ ${ }^{3}$ Krishi Vigyan Kendra, Kalyandurg, Anthapuraram, Andhra Pradesh - 515 761, India \\ *Corresponding author
}

\section{A B S T R A C T}

General and specific combining abilities (GCA and SCA) were estimated using six lines of tomato (Solanum lycopersicum $\mathrm{L}$.) and three testers and their $\mathrm{F}_{1}$ hybrids, bred in line $\mathrm{x}$

\section{Keywords}

General combining ability, Specific

combining ability, Gene action, Line and tester, Tomato

Article Info

Accepted:

18 September 2018 Available Online: 10 October 2018 tester fashion. The present study revealed that none of the parent was best combiner for all the traits indicating differences in genetic variability for different characters among the parents. Line $\mathrm{x}$ tester effect was found significant for all the characters under the study except for plant height. The magnitude of $\mathrm{gca}$ and sca variances indicated importance of additive as well as non-additive gene action with predominance non-additive action for all the traits except plant height. Lines, LE-56 was found good general combiner for ascorbic acid, total carotenoids, reducing sugars, total sugars and lycopene content; LE-62 for plant height, TSS, reducing sugars and total sugars. Similarly tester, Punjab Chhuhara for total carotenoids and lycopene; tester Pusa Gaurav was found to be good combiner for plant height, reducing sugars and total sugars. $\mathrm{F}_{1}$ hybrids from cross combinations, LE-62 $\times$ Punjab Chhuhara were recorded with good specific combiner for number of primary branches per plant, total carotenoids, reducing sugars, total sugars and lycopene; LE-64 $\times$ Punjab Chhuhara for ascorbic acid, total carotenoids and lycopene; EC-165749 X Pusa Gaurav for TSS, reducing sugars and total sugars.

\section{Introduction}

Tomato (Solanum lycopersicum L.) an important vegetable crop grown throughout the world, is not only used as a fresh vegetable but also for processing. Combining ability is an effective tool, which gives genetic information for the choice of parents in terms of performance of their hybrids (Chezhian et al., 2000). For developing hybrids, the most important task for the plant breeder is the choice of parental lines. The selection of parents on the basis of per se performance does not necessarily lead to desirable results (Allard, 1960). It is, therefore essential to find out the combining ability of desirable genotypes to be involved in breeding programme for effective transfer of desirable genes in the resultant progenies. The objective of present investigation was undertaken to identify the best parental combination for growth and quality characters in tomato. 


\section{Materials and Methods}

The present investigation was carried out at the experimental farm of Vegetable Research Station, Dr. Y.S. R. Horticultural University, Rajendranagar, Hyderabad during 2010 2011. The parental material used in the line $x$ tester model, consisted of six lines viz., EC165749, LE-56, LE-62, LE-64, LE-65, LE-67 and three testers viz., d Punjab Chhuhara, Pant $\mathrm{T}-3$ and Pusa Gaurav. Crosses were made manually using the standard procedure of hand emasculation and pollination. All the 18 hybrids along with their corresponding nine parents and three standard checks viz; Lakshmi, US-618 and Arka vikas were evaluated in a randomized block design with three replications. Combining ability analysis was done as per Kempthorne (1957).

Observations were recorded for plant height $(\mathrm{cm})$, number of primary branches per plant, total soluble solids ( $\left.{ }^{\circ} \mathrm{Brix}\right)$, ascorbic acid $(\mathrm{mg} / 100 \mathrm{~g})$, total carotenoids $(\mathrm{mg} / 100 \mathrm{~g})$, teducing sugars (\%), total sugars (\%) and lycopene content $(\mathrm{mg} / 100 \mathrm{~g})$ to study the gene action, general combining ability ( $g c a$ ) effects of parents and specific combining ability $(s c a)$ effects of hybrids in tomato.

\section{Results and Discussion}

Analysis for combining ability was carried out for growth and quality characters and mean sum of squares were presented in Table 1. The analysis of variance revealed that the treatments exhibited highly significant differences among themselves. The parents as well as crosses exhibited significant differences for all the traits studied, whereas parents vs. crosses exhibited significant differences only for plant height, number of primary branches per plant and ascorbic acid. The interaction effects (Lines $\times$ Testers) were found to be significant for all the traits except for plant height.
General combining ability and specific combining ability effects

Nature and magnitude of combining ability effects provide guide line in identifying the better parents and their utilization. The summary of the gca effects of the parents (Table 3) revealed that none of the parent found to be good general combiner for all the characters. Line, LE-56 was found good general combiner for ascorbic acid (11.719), total carotenoids (0.854), reducing sugars (0.367), total sugars (0.353) and lycopene (1.005). Line, LE-62 was observed good combiner for plant height (24.524), TSS (0.641), reducing sugars $(0.613)$ and total sugars (0.621). None of the lines exhibited positive and negative significant $g c a$ effects for number of primary branches per plant. Among the testers, Punjab Chhuhara was observed good combiner for total carotenoids (0.569) and lycopene (0.662). Tester, Pusa Gaurav was found to be good combiner for plant height (6.835), reducing sugars (0.135) and total sugars $(0.140)$. None of the testers exhibited positive and negative significant $g c a$ effects for ascorbic acid.

In the case of $s c a$ effects, none of the hybrids exhibited favourable sca effect for all the characters (Table 4). Of all the crosses studied none of the crosses found to be significant, except LE-64 $\times$ Punjab Chhuhara (-16.03) which recorded significant negative $s c a$ effect for plant height. Hybrid, LE-62 $\times$ Punjab Chhuhara was recorded with good specific combiner for number of primary branches per plant (1.388), total carotenoids (1.051), reducing sugars $(0.454)$, total sugars $(0.430)$ and lycopene (1.587). Cross combination, LE$64 \times$ Punjab Chhuhara was found to be good specific combiner for ascorbic acid (6.559), total carotenoids (1.288) and lycopene (1.478). Cross, EC-165749 X Pusa Gaurav reflected good sca for TSS (0.893), reducing sugars (1.054) and total sugars (0.733). 
Table.1 Analysis of variance for combining ability for growth and quality characters in tomato

\begin{tabular}{|c|c|c|c|c|c|c|c|c|c|}
\hline \multirow[b]{2}{*}{ Source } & \multirow[b]{2}{*}{ df } & \multicolumn{8}{|c|}{ Mean Sum of Squares } \\
\hline & & $\begin{array}{l}\text { Plant height } \\
\text { (cm) }\end{array}$ & $\begin{array}{l}\text { No. of primary } \\
\text { branches/ plant }\end{array}$ & TSS ( ${ }^{\circ}$ Brix) & $\begin{array}{c}\text { Ascorbic } \\
\text { acid } \\
(\mathbf{m g} / 100 \mathrm{~g})\end{array}$ & $\begin{array}{c}\text { Total } \\
\text { carotenoid } \\
(\mathrm{mg} / 100 \mathrm{~g})\end{array}$ & $\begin{array}{c}\text { Reducing } \\
\text { sugars } \\
(\%)\end{array}$ & $\begin{array}{c}\text { Total } \\
\text { sugars }(\%)\end{array}$ & $\begin{array}{l}\text { Lycopene } \\
\text { (mg/100 g) }\end{array}$ \\
\hline Replications & 2 & 41.3091 & 0.0640 & 0.0448 & 3.8258 & 0.1816 & 0.1485 & 0.0402 & 0.1276 \\
\hline Treatments & 26 & $1316.7109^{* *}$ & $3.7655^{* *}$ & $0.8985^{* *}$ & $188.8397^{* *}$ & $6.6041^{* *}$ & $1.0354^{* *}$ & $0.8921^{* *}$ & $7.3981^{* *}$ \\
\hline $\begin{array}{l}\text { Parents } \\
\end{array}$ & 8 & $855.5489^{* * *}$ & $3.1379^{* *}$ & $1.0657^{* *}$ & $76.4032^{* *}$ & $7.5321^{* *}$ & $1.1842^{* *}$ & $1.1233^{* *}$ & $5.9124^{* *}$ \\
\hline Parents (Line) & 5 & $1200.2116^{* *}$ & $2.6036^{* *}$ & $1.0062^{* *}$ & $112.0482^{* * *}$ & $10.7523^{* *}$ & $0.9204^{* *}$ & $0.9392^{* *}$ & $7.7579^{* *}$ \\
\hline Parents (Testers) & 2 & 211.1054 & $5.0411^{* *}$ & $1.5511^{* *}$ & 16.4444 & $3.2288^{* *}$ & $2.2639^{* *}$ & $1.9880^{* *}$ & $4.0224^{* *}$ \\
\hline Parents (L vs T) & 1 & 421.1230 & $2.0030^{* *}$ & $0.3919^{*}$ & 18.0961 & 0.0379 & $0.3440^{*}$ & $0.3143^{*}$ & 0.4648 \\
\hline Parents vs Crosses & 1 & $3399.3677^{* *}$ & $1.7735^{* *}$ & 0.0089 & $65.0433^{* *}$ & 0.3326 & 0.0214 & 0.0045 & 0.6309 \\
\hline Crosses & 17 & $1411.2190^{* *}$ & $4.1781^{* *}$ & $0.8721^{* *}$ & $249.0330^{* * *}$ & $6.5363^{* *}$ & $1.0250^{* *}$ & $0.8355^{* *}$ & $8.4952^{* *}$ \\
\hline Line Effect & 5 & $3706.9396^{* *}$ & 0.5265 & 1.2803 & 526.7154 & 4.2635 & 1.5803 & 1.4675 & 3.8586 \\
\hline Tester Effect & 2 & $1377.4990^{*}$ & 3.6239 & 0.5469 & 6.7761 & 8.8826 & 0.3214 & 0.3020 & 9.6413 \\
\hline Line " Tester Eff. & 10 & 270.1027 & $6.1148^{* *}$ & $0.7331^{* *}$ & $158.6432^{* * *}$ & $7.2035^{* *}$ & $0.8881^{* *}$ & $0.6262^{* *}$ & $10.5843^{* *}$ \\
\hline Error & 52 & 166.7301 & 0.2422 & 0.0756 & 7.4309 & 0.2903 & 0.0503 & 0.0707 & 0.2734 \\
\hline Total & 80 & 537.3383 & 1.3828 & 0.3423 & 66.2986 & 2.3395 & 0.3729 & 0.3369 & 2.5853 \\
\hline
\end{tabular}

Table.2 Analysis of variance for combining ability for growth and quality characters in tomato

\begin{tabular}{|c|c|c|c|c|}
\hline S. No. & Character & $\sigma^{2} G C A$ & $\sigma^{2} S C A$ & $\sigma^{2} G C A / \sigma^{2} S C A$ \\
\hline 1 & Plant height & 175.9622 & 34.4575 & 5.1066 \\
\hline 2 & No. of primary branches per plant & 0.1358 & 1.9575 & 0.069 \\
\hline 3 & TSS ( ${ }^{\circ}$ Brix) & 0.0621 & 0.2192 & 0.5665 \\
\hline 4 & Ascorbic acid (mg/100 g) & 19.2085 & 50.4041 & 0.3811 \\
\hline 5 & Total carotenoids $(\mathrm{mg} / 100 \mathrm{~g})$ & 0.4654 & 2.3044 & 0.2020 \\
\hline 6 & Reducing sugars (\%) & 0.0667 & 0.2793 & 0.2389 \\
\hline 7 & Total sugars $(\%)$ & 0.0603 & 0.1852 & 0.3257 \\
\hline 8 & Lycopene (mg/100 g) & 0.4797 & 3.4370 & 0.1396 \\
\hline
\end{tabular}

Table.3 Estimates of general combining ability ( $\mathrm{gca}$ ) effects of parents for growth and quality characters in tomato

\begin{tabular}{|c|c|c|c|c|c|c|c|c|}
\hline & $\begin{array}{l}\text { Plant } \\
\text { height } \\
(\mathrm{cm})\end{array}$ & $\begin{array}{c}\text { No. of primary } \\
\text { branches/ } \\
\text { plant }\end{array}$ & $\begin{array}{c}\text { TSS } \\
\left({ }^{\circ} \text { Brix }\right)\end{array}$ & $\begin{array}{l}\text { Ascorbic acid } \\
\text { (mg/100 g) }\end{array}$ & $\begin{array}{c}\text { Total } \\
\text { carotenoid } \\
(\mathrm{mg} / \mathbf{1 0 0} \mathrm{g})\end{array}$ & $\begin{array}{c}\text { Reducing } \\
\text { sugars }(\%)\end{array}$ & $\begin{array}{c}\text { Total } \\
\text { sugars } \\
(\%)\end{array}$ & $\begin{array}{l}\text { Lycopene } \\
(\mathrm{mg} / 100 \mathrm{~g})\end{array}$ \\
\hline \multicolumn{9}{|l|}{ Lines } \\
\hline EC - 165749 & $-16.581^{* *}$ & 0.179 & $-0.326^{* *}$ & $-8.262^{* *}$ & $-0.451^{*}$ & $-0.342^{* *}$ & $-0.272^{* *}$ & -0.133 \\
\hline LE - 56 & $-14.102^{* *}$ & 0.055 & $0.196^{*}$ & $11.719^{* *}$ & $0.854^{* *}$ & $0.367^{* *}$ & $0.353^{* *}$ & $1.005^{* *}$ \\
\hline LE - 62 & $24.524^{* *}$ & -0.291 & $0.641^{* *}$ & $-3.392^{* *}$ & -0.250 & $0.613^{* *}$ & $0.621^{* *}$ & -0.094 \\
\hline LE - 64 & -1.524 & -0.018 & -0.137 & $5.719^{* *}$ & $0.649^{* *}$ & $-0.199^{*}$ & -0.178 & $0.355^{*}$ \\
\hline LE - 65 & $25.664^{* *}$ & 0.329 & -0.004 & $-6.503^{* *}$ & 0.160 & 0.020 & -0.084 & -0.155 \\
\hline LE - 67 & $-17.980^{* *}$ & -0.254 & $-0.370^{* *}$ & 0.719 & $-0.962^{* *}$ & $-0.460^{* *}$ & $-0.439^{* *}$ & $-0.978^{* *}$ \\
\hline $\mathrm{SE}_{(\mathrm{i})}$ & 4.304 & 0.164 & 0.092 & 0.909 & 0.180 & 0.075 & 0.089 & 0.174 \\
\hline SE(i-j) & 6.087 & 0.232 & 0.130 & 1.285 & 0.254 & 0.106 & 0.125 & 0.247 \\
\hline \multicolumn{9}{|l|}{ Testers } \\
\hline Punjab Chhuhara & $-9.859^{* *}$ & -0.217 & $-0.198^{* *}$ & 0.108 & $0.569^{* *}$ & $-0.132^{*}$ & -0.116 & $0.662^{* *}$ \\
\hline Pant T - 3 & 3.024 & $0.516^{* *}$ & 0.069 & -0.660 & $-0.785^{* * *}$ & -0.002 & -0.024 & $-0.786^{* *}$ \\
\hline Pusa Gaurav & $6.835^{*}$ & $-0.299^{*}$ & 0.130 & 0.552 & 0.216 & $0.135^{*}$ & $0.140^{*}$ & 0.124 \\
\hline $\mathbf{S E}_{(\mathbf{i})}$ & 3.044 & 0.116 & 0.065 & 0.643 & 0.127 & 0.053 & 0.063 & 0.123 \\
\hline SE (i-j) & 4.304 & 0.164 & 0.092 & 0.909 & 0.180 & 0.075 & 0.089 & 0.174 \\
\hline
\end{tabular}


Table.4 Estimates of specific combining ability ( $s c a$ ) effects of hybrids for growth and quality characters in tomato

\begin{tabular}{|c|c|c|c|c|c|c|c|c|}
\hline Crosses & $\begin{array}{l}\text { Plant } \\
\text { height } \\
\text { (cm) }\end{array}$ & $\begin{array}{l}\text { No. of primary } \\
\text { branches/ plant }\end{array}$ & $\begin{array}{c}\text { TSS } \\
\left({ }^{\circ} \text { Brix }\right)\end{array}$ & $\begin{array}{c}\text { Ascorbic } \\
\text { acid } \\
(\mathrm{mg} / 100 \mathrm{~g})\end{array}$ & $\begin{array}{c}\text { Total } \\
\text { carotenoid } \\
(\mathrm{mg} / 100 \mathrm{~g})\end{array}$ & $\begin{array}{c}\text { Reducing } \\
\text { sugars } \\
(\%)\end{array}$ & $\begin{array}{c}\text { Total } \\
\text { sugars } \\
(\%)\end{array}$ & $\begin{array}{c}\text { Lycopene } \\
(\mathrm{mg} / 100 \mathrm{~g})\end{array}$ \\
\hline EC -165749 × Punjab Chhuhara & 0.336 & $-0.672^{*}$ & $-0.346^{*}$ & $5.540^{* *}$ & 0.062 & $-0.589^{* *}$ & $-0.381^{*}$ & -0.414 \\
\hline EC $-165749 \times$ Pant T-3 & 0.098 & $1.262^{* *}$ & $-0.546^{* *}$ & -2.635 & $0.756^{*}$ & $-0.465^{* *}$ & $-0.352^{*}$ & $0.731^{*}$ \\
\hline EC -165749 × Pusa Gaurav & -0.434 & $-0.590^{*}$ & $0.893^{* *}$ & -2.905 & $-0.818^{*}$ & $1.054^{* *}$ & $0.733^{* *}$ & -0.317 \\
\hline LE-56 × Punjab Chhuhara & -4.586 & -0.459 & 0.165 & -1.775 & $0.696^{*}$ & 0.109 & 0.034 & $0.962^{* *}$ \\
\hline LE-56 $\times$ Pant T-3 & 1.699 & 0.159 & -0.069 & 0.994 & $-1.239^{* * *}$ & -0.114 & -0.153 & $-1.607^{* *}$ \\
\hline LE-56 × Pusa Gaurav & 2.887 & 0.300 & -0.096 & 0.781 & 0.543 & 0.005 & 0.119 & $0.646^{*}$ \\
\hline LE-62 $\times$ Punjab Chhuhara & 10.039 & $1.388^{* *}$ & $0.354^{*}$ & -1.330 & $1.051^{* *}$ & $0.454^{* *}$ & $0.430^{* *}$ & $1.587^{* *}$ \\
\hline LE-62 × Pant T-3 & -9.927 & -0.001 & $0.387^{*}$ & $-7.229^{* *}$ & $1.015^{* *}$ & $0.277^{*}$ & 0.166 & $1.215^{* *}$ \\
\hline LE-62 x Pusa Gaurav & -0.112 & $-1.386^{* *}$ & $-0.741^{* *}$ & $8.559^{* *}$ & $-2.066^{* *}$ & $-0.730^{* *}$ & $-0.596^{* *}$ & $-2.802^{* *}$ \\
\hline LE-64 × Punjab Chhuhara & $-16.030^{*}$ & 0.425 & 0.198 & $6.559^{* *}$ & $1.288^{* *}$ & $0.268^{*}$ & 0.302 & $1.478^{* *}$ \\
\hline LE-64 $\times$ Pant T-3 & 8.688 & $-2.331^{* *}$ & -0.235 & $5.660^{* *}$ & $-1.554^{* * *}$ & $-0.269^{*}$ & $-0.359^{*}$ & $-1.741^{* *}$ \\
\hline LE-64 × Pusa Gaurav & 7.343 & $1.907^{* *}$ & 0.037 & $-12.219^{* *}$ & 0.266 & 0.001 & 0.057 & 0.262 \\
\hline LE-65 $\times$ Punjab Chhuhara & 3.582 & -0.555 & -0.069 & -2.886 & $-2.449^{* *}$ & -0.114 & -0.166 & $-2.858^{* *}$ \\
\hline LE-65 $\times$ Pant T-3 & -6.134 & -0.405 & 0.065 & $4.549^{* *}$ & $0.945^{* *}$ & 0.166 & 0.193 & $1.036^{* *}$ \\
\hline LE-67 × Punjab Chhuhara & 6.659 & -0.126 & -0.302 & $-6.108^{* *}$ & $-0.647^{*}$ & -0.128 & -0.220 & $-0.755^{*}$ \\
\hline LE-67 × Pant T-3 & 5.576 & $1.317^{* *}$ & $0.398^{*}$ & -1.340 & 0.077 & $0.406^{* *}$ & $0.506^{* *}$ & 0.366 \\
\hline LE-67 x Pusa Gaurav & -12.235 & $-1.191^{* *}$ & -0.096 & $7.448^{* *}$ & 0.570 & $-0.278^{*}$ & -0.286 & 0.389 \\
\hline SE(i) & 7.455 & 0.284 & 0.159 & 1.574 & 0.311 & 0.130 & 0.154 & 0.302 \\
\hline SE(ij-kl) & 10.543 & 0.402 & 0.225 & 2.226 & 0.440 & 0.183 & 0.217 & 0.427 \\
\hline SE (ij-ik) & 16.105 & 0.614 & 0.343 & 3.400 & 0.672 & 0.280 & 0.332 & 0.652 \\
\hline
\end{tabular}

Hybrid, LE-65 × Pant T-3 was recorded with good specific combiner for ascorbic acid (4.549), total carotenoids (0.945) and lycopene (1.036). Cross combination, LE-67 $\times$ Pant T-3 was found to be good specific combiner for number of primary branches per plant (1.317), reducing sugars (0.406) and total sugars $(0.506)$.

The estimates of general combining ability (gca) and specific combining ability (sca) variances, their ratios and gene action are presented in Table 2. In the present study, the results revealed that the variance due to sca were higher in magnitude than the variance due to gca for the characters number of primary branches per plant, TSS, ascorbic acid, total carotenoids, reducing sugars, total sugars and lycopene, which indicated the predominance of non-additive gene action. The results of the present investigation on components of heritable variation indicated the predominance of non-additive gene action over the additive component for growth characters and quality parameters under study, which is ideal for exploitation through heterosis breeding and recombination breeding. These results are in accordance with the findings of Dharmatti et al., (2001), Pandey et al., (2006) and Singh et al., (2010) for number of primary branches per plant, Mondal et al., (2009) for TSS, carotenoid content and total sugars, Joshi and Kohli (2006) and Pandey et al., (2006) for ascorbic acid, Roopa et al., (2001) and Kumari and Srivastava (2007) for lycopene.

The ratio of $g c a$ variance to $s c a$ variance is more than unity $(>1)$ for plant height indicating the preponderance of additive gene action involved in the inheritance of these traits. The present results are in line with the earlier reports of Premlakshmi et al., (2005) and Saidi et al., (2008). 
It can be concluded that a particular line and tester parent or hybrid cultivar cannot be used to evaluate all the characters with equal efficiencies. Thus, parents selection should be made after detailed evaluation of gca and sca effects. The results indicated that the cross, LE-62 $\times$ Punjab Chhuhara was a good specific combiner for number of primary branches per plant, total carotenoids, reducing sugars, total sugars and lycopene; LE-64 $\times$ Punjab Chhuhara for ascorbic acid, total carotenoids and lycopene; EC-165749 X Pusa Gaurav for TSS, reducing sugars and total sugars.

\section{References}

Allard, R. W., 1960. Principles of Plant Breeding. John Willey and Sons. Inc. London, pp. 83-108.

Chezhian, P., Babu, S., and Ganesan, J., 2000. Combining ability in egg plant. J Trop Agric Res., 12: 394-97.

Dharmatti, P. R., Madalageri, B. B., Patil, R. V., Mannikeri, I. M., and Patil, G., 2001. Combining ability studies in summer tomato. Karnataka Journal of Agricultural Sciences, 14(2): 417-422.

Joshi, A., and Kohli, U. K., 2006. Combining ability and gene action studies for processing quality attributes in tomato (Lycopersicon esculentum Mill.). Indian Journal of Horticulture, 3(3): 289-293.

Kempthorne, O., 1957. An Introduction to genetic Statistic. John Wiley and Sons, Inc. New York. pp: 208-223.

Kumari, W., and Srivastava, J. P., 2007. Combining ability of quality traits and yield in tomato (Solanum lycopersicon (Mill.) WETTSD). Vegetable Science, 34(1): 99-100.

Mondal, C., Sarkar, S., and Hazra, P., 2009. Line $\mathrm{x}$ Tester analysis of combining ability in tomato (Lycopersicon esculentum Mill.). Journal of Crop and Weed, 5(1): 53-57.

Pandey, S. K., Dixit, J., Pathak, V. N., and Singh, P. K., 2006. Line $\mathrm{x}$ Tester analysis for yield and quality characters in tomato (Solanum lycopersicon (Mill.) WETTSD). Vegetable Science 33(1): 13-17.

Premalakshmi, V., Thangaraj, T., Veeraragavathatham, D., and Arumugam, T., 2005. Heterosis and combining ability in tomato (Solanum lycopersicum L.). Vegetable Science, 32(1): 47-50.

Roopa, L., Sadashiva, A. T., Reddy, K. M., Gopalakrishna Rao, K. P., and Narasimhaprasad, B. C., 2001. Combining ability studies for long shelf life in tomato. Vegetable Science, 28(1): 24-26.

Saidi, M., Waradae, S. D., and Prabu, T., 2008. Combining ability estimates for yield and its contributing traits in Tomato (Lycopersicon esculentum). International Journal of Agriculture and Biology, 10(2): 238-240.

Singh, B., Kaul, S., Kumar, D., and Kumar, V., 2010. Combining ability for yield and its contributing characters in tomato. Indian Journal of Horticulture, 67(1): 50-55.

\section{How to cite this article:}

Madhavi, Y., R.V.S.K. Reddy and Sreenivasa Reddy, C. 2018. Combining Ability Studies for Growth and Quality Characters in Tomato (Solanum lycopersicum L.). Int.J.Curr.Microbiol.App.Sci. 7(10): 2287-2291. doi: https://doi.org/10.20546/ijcmas.2018.710.264 